\title{
Refining in Nigeria: history, challenges and prospects
}

\author{
Anthony Ogbuigwe ${ }^{1}$ (I)
}

Received: 23 June 2018 / Accepted: 18 September 2018 / Published online: 27 September 2018

(c) The Author(s) 2018

\section{Abstract}

There are four major existing refineries as follows:

- Old Port Harcourt Refinery; capacity 60,000 bpsd commissioned in 1965.

- Warri Refining and Petrochemical Company; capacity 125,000 bpsd commissioned in 1978.
- Kaduna Refining and Petrochemical Company; capacity 110,000 bpsd commissioned in 1980.

- New Port Harcourt Refinery; capacity 150,000 bpsd commissioned in 1989.

Thus, the total installed capacity is 445,000 bpsd. These plants in the last 15-20 years had a poor operating record with average capacity utilization hovering between 15 and $25 \%$ per annum. As a result, $70-80 \%$ of the national petroleum products demand is met through import. As at 2017, the aggregate demand of petroleum products in Nigeria was equivalent to $750,000 \mathrm{bpsd}$. Hence, there is ample scope for investment in new plants and revamp of the existing ones to make them more efficient. This paper traces the history of refining in Nigeria, highlights the current poor record of capacity utilization, proffers solutions for improving their viability, and presents prospects for growth of the industry in Nigeria.

Keywords Capacity utilisation · Governance · Pipeline vandalisation · Turnaround maintenance

\section{History of Nigerian refining}

\section{The Nigeria Petroleum Refining Company (NPRC)}

Exploration for crude oil commenced in Nigeria in 1937 when Shell D'Arcy was granted the sole concessionary rights over the whole territory of the country [Nigerian National Petroleum Corporation (NNPC) [1]]. Crude Oil was first discovered in commercial quantity in Oloibiri in present-day Bayelsa State in 1956 when Shell D'Arcy drilled the first successful well [2-4]. That same year, Shell D'Arcy changed its name to Shell-BP Petroleum Development Company of Nigeria Limited. It continued development activities in 1957 and the first shipment of crude oil from Nigeria took place in 1958 [1]. According to Fayose as quoted by Oloruntegbe et al. "The first cargo of crude oil was shipped in February 1958 through the oil tanker ship Hemisfusus to Britain" (Oloruntegbe, K. O., Akinsete, M. A., Odutuyi, M.

Anthony Ogbuigwe

tony.ogbuigwe@pejadegroup.com

1 PEJAD Nigeria Limited, 6A Tito Broz Street, Abuja, Nigeria
O. 2009) [5]. As the economy of the nation grew, demand for petroleum products was met by importation. Shortly after independence, the Shell-BP Petroleum Development Company saw an opportunity to meet the product needs of the country. It embarked on a project to build the first refinery in the country near Port Harcourt. The 38,000 barrels per day (bpsd) Shell-BP Refinery was completed and commissioned in 1965. It was a simple hydro-skimming plant. The Federal Government of Nigeria acquired 50\% shareholding under a participatory agreement with Shell-BP. It was registered as the Nigeria Petroleum Refining Company (NPRC) in 1972 when the Government of Nigeria increased its shareholding to $60 \%$, but it remained as a JV Company under private sector control and management (NPRC Company reports 1972).

The premier refinery was debottlenecked in 1972 and a Naphtha Catalytic Refining Unit (CRU) added. The capacity was increased to 60,000 bpsd. The plant met all the normal petroleum product needs of the country except for bitumen which was still imported. The refinery was a fully private company and sold its products directly to the marketing companies in Nigeria under an arrangement in which they paid for stated capacities of crude supplied, lifted products 
realizable from those capacities, and paid the refinery a processing fee accordingly. It was a very efficient and profitable arrangement for all parties involved. The Federal Government earned tax revenue and excise duty.

The Federal Government acquired the remaining 40\% shares in 1978 under an outright buy out, and renamed it NNPC Refinery, Port Harcourt [1]. It was thereafter fully Nigerianised and came under Government control. This acquisition occurred just a year after the formation of the Nigerian National Petroleum Corporation (NNPC) in 1977. The NNPC was created as a merger of the Nigerian National Oil Corporation (NNOC) and the Ministry of Petroleum, and was manned mainly by professionals who were recruited from the private sector International Oil Companies (IOCs) to grow capability for Nigeria to be an active player in the fast developing Oil Industry in Nigeria.

It may be necessary to state that the geopolitics of oil influenced several decisions made in the early years of the industry in Nigeria. Nigeria joined the Organisation of Petroleum Exporting Countries (OPEC) in 1971. (Danielsen 1982; Sonny Atumah 2016, Vanguard Publications). OPEC was founded in 1960 to coordinate the petroleum policies of its members and to provide member states with technical and economic aid. As a grouping of petroleum exporting countries, it could be argued that a major objective was to wrest control of pricing of crude oil from the IOCs, and increase the take by the host country Governments. To a large extent, they have succeeded.

A publication by Ugwukah and Ohaja [6] puts this in perspective: "Nigeria's proven oil reserves are estimated by the United States Energy Information Administration (USEIA) as between 16 and 22 billion barrels $\left(3.5 \times 109 \mathrm{~m}^{3}\right)$, but other sources claims there could be as much as 35.3 billion barrels $\left(5.61 \times 109 \mathrm{~m}^{3}\right)$. Its reserves make Nigeria, the tenth most petroleum-rich nation and, by far, the most affluent in Africa. Nigeria has a total of 159 oil fields and 1481 wells in operation, according to The Ministry of Petroleum Resources. Nearly, all other country's primary reserves are conciliated in and around the delta of the Niger River but off-shore rigs are also prominent in the well-endowed coastal region. Nigeria's petroleum is classified mostly as "light" and "sweet" as the oil is largely free of Sulphur. Nigeria is the largest producer of sweet oil in OPEC. The sweet oil is similar in composition to the petroleum extracted from the North Sea. This crude oil is known as "Bonny light". Other crude oil types found in Nigeria named after their export terminals are Qua Iboe, Escravos Blend, Brass River, Forcados and Pennington Anfani" [6]. By the late 1960s and early 1970s, Nigeria had attained a production level of over two million barrels of crude oil per day [1]. This oil wealth and their large population gave Nigeria a voice.

\section{NNPC refineries}

By the mid-1970s, projections by the economic surveillance unit of the NNOC indicated that at the rate the economy was growing, demand for petroleum products would outstrip production by NPRC. Thus, the NNOC commenced work on a project to build a second refinery to be sited in Warri. The Warri Refinery Project was completed in December 1977, and commissioned early in 1978. It was a 100,000 bpsd conversion plant, complete with a naphtha catalytic reforming unit (CRU) and a Fluid Catalytic Conversion unit (FCCU) for gasoline. Again all the petroleum product needs of the country were being fully met from both existing refineries.

Economic activity was growing in the northern as well as in the southern parts of the country. Products were being delivered by long haul trucks to the North as well as rail. Kano and Kaduna were experiencing rapid growth, as well as sections of the middle Belt. Projections again indicated that by the mid-1980s, demand would outstrip the production capacity of the two existing refineries. It was, therefore, decided to build a third refinery and locate same in Kaduna closer to the high demand areas in the North. The Kaduna Refinery was completed and commissioned in 1980. Like the Warri Refinery, it was a modern conversion refinery, but had two parts: a 50,000 bpsd Fuels Plant with a CRU and an FCCU; and a 50,000 bpsd Lubes Plant for production of lubricating oil blendstocks and waxes and bitumen. Waxy crude required as feedstock for the Lubes Plant was imported from Saudi Arabia and Venezuela as all Nigerian crudes were napthenic [7]. Again the Kaduna Refinery was successfully commissioned by NNPC and ran at full capacity utilization.

\section{NNPC organization structure}

The NNPC was established by a special Act which gave it autonomy as a Corporation [8]. Though a National Oil Corporation (NOC), it was run by professionals who had come mainly from the private sector. They were allowed to operate under governance by a Board appointed by Government with professionals and a representative from the Ministry of Finance Incorporated (MOFI). MOFI was the investment arm of the government, and hence had an eye for profitability and efficiency. The Minister of Petroleum was the Chairman of the Board. Thus, the corporation was allowed autonomy to run its affairs, maintain assets and run these government investments to a large degree without political interference, except to obtain approvals as needed from time to time from the Minister of Petroleum. The Petroleum Act gave the Minister the necessary authority to exercise these powers. Under this arrangement, capacity utilization by the Refineries was same as existed elsewhere in the world, 
maintenance was carried out in a timely fashion, and all operating and maintenance costs and expenses (including staff salaries and benefits) were met without recourse to the Federation account. The refineries paid dividends and profits to the Government.

The NNPC had an efficient Economic Intelligence Unit, and a Product Supply and Distribution Unit that continuously monitored consumption pattern of petroleum products in Nigeria. Projections in 1983 again indicated that based on the pace of economic activity, a deficit of supply would develop by 1989 . Thus, the New Refinery Project was conceived. NNPC intended to go into export of petroleum products. Hence, two refineries were planned; a 100,000 bpsd in Port Harcourt and another 100,000 bpsd plant to be sited in Calabar where there was a deep sea draught. The second plant was to be solely for export. The two projects were commenced at the same time. Basic Engineering Design was completed and Licensor Process Design packages were also completed by Q3 1984. Unfortunately, at that stage, Government decided that only one 150,000 bpsd refinery should be built in Port Harcourt. Thus, only the New Port Harcourt Refinery Project was approved and awarded early in 1985. The refinery was completed and commissioned by NNPC in 1989 at design capacity. After satisfying all local demands, extra products were exported efficiently. Design capacities for the three refineries are stated in Table 1.

\section{Decline in performance of existing refineries}

The decline in the performance of the local refineries started in the early 1990s after the military Government ordered NNPC to close its accounts in commercial banks and transfer them to the Central Bank. NNPC lost its autonomy. It became increasingly subjected to interference and directives by politicians. It could no longer ensure prompt maintenance of the refineries. Most importantly, decisions on when to carry out turnaround maintenance and which contractor to execute it came under the influence of the Government rather than by the professionals within the corporation. Things very quickly went downhill thereafter as a result. The figure that follows illustrates the decline in capacity utilization that resulted (Source: NNPC Refineries Performance Reports 2012).

Whereas Fig. 1 above represents the average capacity utilization for the three refineries over the period 1997-2005, Table 2 below is indicates the capacity utilization for the New Port Harcourt Refinery alone. The construction of this refinery was completed in 1989. The first year operation covered only about 7 months. The decline from 1997 onwards is evident.

\section{Challenges facing existing refineries}

The sorry situation of low capacity utilization which developed and still exists today is due to the following reasons:

1. Poor governance.

2. No major turnaround maintenance has been carried out in any of these refineries since 2008. The last TAM in PHRC was carried out in 2000. This should be viewed against the established best practice worldwide that TAM should be conducted by refineries every two or maximum 3 years.

3. Pipelines supplying crude oil to the refineries, and those conveying products from them are routinely vandalized. This leads to massive loss of revenue and worsens the problem of under-recovery of crude cost.

4. Even if the refineries were able to operate consistently, the price of Premium Motor Spirit (PMS) is regulated by Government, leading to serious under-recovery of crude cost.

Table 1 Nigerian refineries design capacities, configuration and yields

\begin{tabular}{llll}
\hline & Port Harcourt & Warri & Kaduna \\
\hline Capacity MTA & 10.5 & 6.0 & 5.5 \\
Commissioning date & 1988 & 1978 & 1980 \\
Refinery configuration & CDU/CCR/ FCC & CDU/CRU/ FCC/PP & CDU/CRU/FCC/ lubes/wax \\
Additional processes/petro- & Dimersol/alky & Carbon black (18)/PP(13) & Asphalt(3O0)/LAB(30) benzene(15) \\
$\quad$ chemicals & & & \\
Crude supply & P/L from Bonny & P/L from Escravos & P/L from Escravos via Warri \\
Design PMS & 3.0 & 2.1 & 1.3 \\
Design DPK & 1.4 & 0.5 & 0.6 \\
Design AGO & 2.4 & 1.7 & 1.0 \\
\hline
\end{tabular}

MTA is metric tons per annum, $P / L$ means by pipeline 
Fig. 1 Average capacity utilization for three refineries

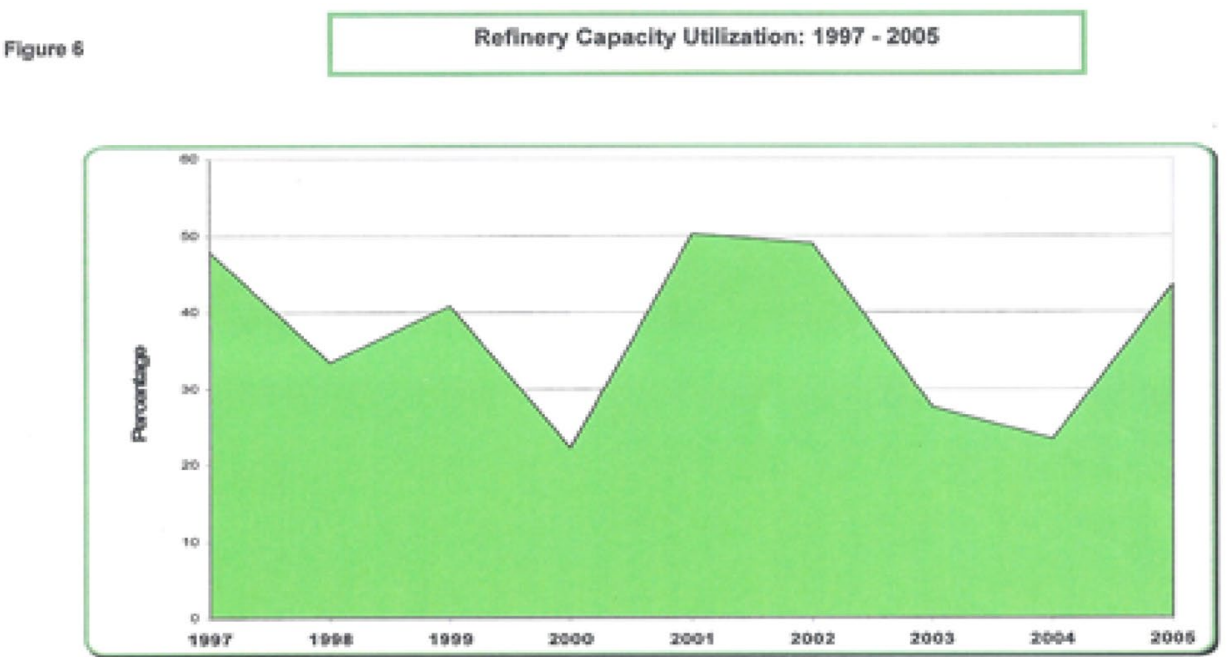

Table 2 Average annual capacity utilization for new Port Harcourt refinery

\begin{tabular}{lllllllllll}
\hline Year & 1989 & 1990 & 1991 & 1992 & 1993 & 1994 & 1995 & 1996 & 1997 & 1998 \\
\hline Capacity utilization \% & 66 & 93 & 90 & 76 & 85 & 58 & 76 & 58.4 & 69 & 54.3 \\
\hline Year & 1999 & 2000 & 2001 & 2002 & 2003 & 2004 & 2005 & 2006 & 2007 & 2008 \\
\hline Capacity utilization \% & 55.7 & 31.1 & 60.7 & 51.4 & 50.5 & 30.7 & 38.1 & 45.7 & 23.8 & 48.5 \\
\hline
\end{tabular}

\section{Poor governance}

The problem of poor governance has been recognized as a key factor that has affected the performance of the refineries. The refineries are $100 \%$ owned by the Government and have no independent control of or access to their funds. All requests for funds to carry out maintenance are subject to multilayer bureaucratic processes. Approvals for any meaningful maintenance are subjected to considerations first by the refinery management committee, thereafter by the corporate refineries directorate, then by the corporate management committee, followed by the corporate board and finally by the National Federal Executive Committee chaired by the President of the Nation, depending on the amounts required. These processes often require months to go through the various stages. Refineries cannot run reliably in this manner.

Outright commercialization or outright divestment of significant equity has been promoted as a solution to this malaise. The Petroleum Industry Bill which was first presented to the National Assembly in 2007 was intended to introduce better governance along these lines. Unfortunately, the bill has been considered by successive assemblies, but is yet to be passed nor signed into law.

\section{The impact of non-performance of turnaround maintenance}

Typically, a petroleum refinery is a complex manufacturing plant designed to convert crude oil feedstock into a definite number and types of petroleum products. The types of products fall into two major categories, namely fuel products and lubricating products.

The fuel refinery is designed to produce five types of products namely:

- LPG (liquefied petroleum gas or cooking gas).

- PMS (premium motor spirit) or petrol.

- DPK (dual purpose kerosene).

- AGO (automotive gas oil) or diesel.

- Fuel oil.

Best practice is that a Refinery is designed and built to produce defined quantities and specifications (quality) of each of these products operating in a continuous manner without interruption for 24-36 months based on proper maintenance culture, before it is systematically shut down for a period, to carry out Turn around maintenance (TAM). When TAM is unduly delayed, performance of the refinery declines. Figure 2 [9] that follows illustrates what could have been produced by the Port Harcourt Refinery if it were 
Fig. 2 Capacity utilization postTAM/rehab

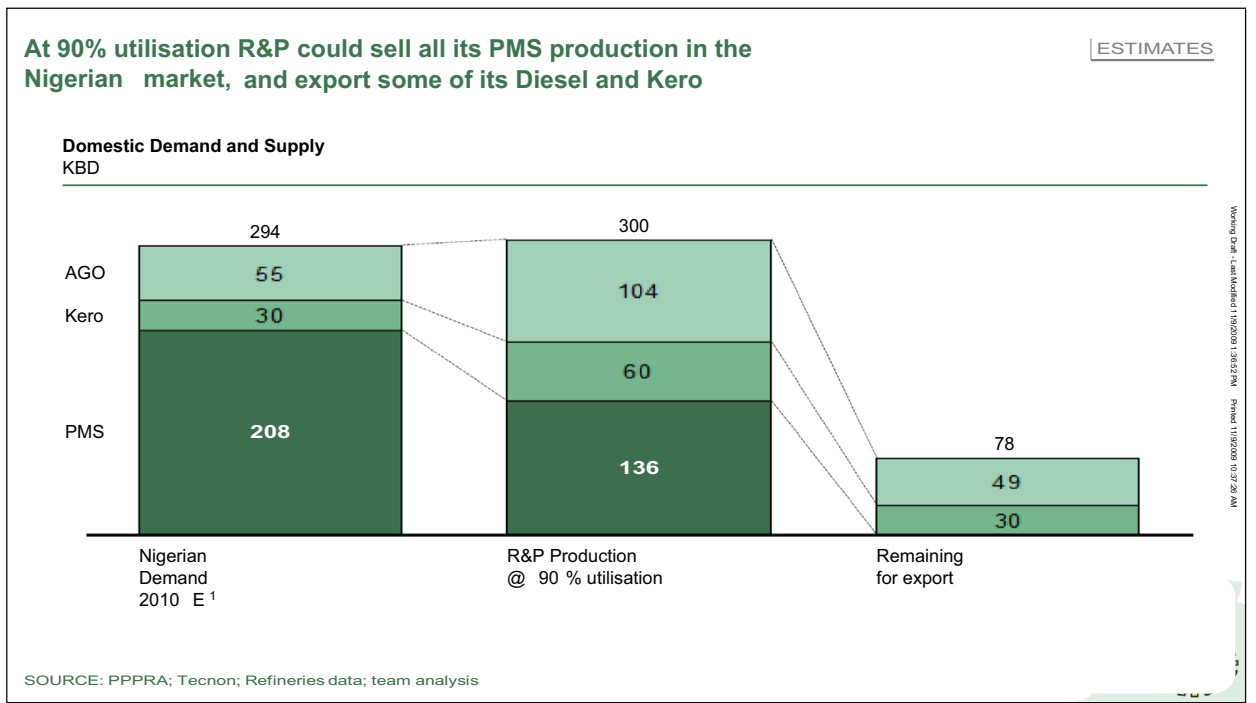

Table 3 Key indicators

\begin{tabular}{|c|c|c|c|c|c|}
\hline \multirow[t]{2}{*}{ Indicators } & \multirow{2}{*}{$\begin{array}{l}2012 \\
\text { QTR } 2 \text { actual }\end{array}$} & \multicolumn{4}{|l|}{2013} \\
\hline & & QTR 2 actual & Year to date plan & Year to $\mathrm{c}$ & ate actual \\
\hline Crude oil receipt (MT) & 0 & 169,122 & $1,067,230$ & 795,277 & \\
\hline Crude oil processed (MT) & 73,822 & 231,343 & $1,067,230$ & 865,033 & \\
\hline Cap. utilization (\%) & & & 20.61 & 23.58 & Combined actual capacity utilisation of NPHR \& \\
\hline NPHR & 3.92 & 12.48 & (Based on com- & 0.0 & OPHR is $16.84 \%$ \\
\hline OPHR & 0.0 & 0.0 & & & \\
\hline On-stream eff. (\%) & & & 31 & & \\
\hline NPHR & 6.14 & 20.43 & & 37.58 & \\
\hline OPHR & 0.0 & 0.0 & & 0.0 & \\
\hline
\end{tabular}

PHRC performance was limited by inadequate supply of Bonny Light Crude oil

Fig. 3 PHRC operational performance

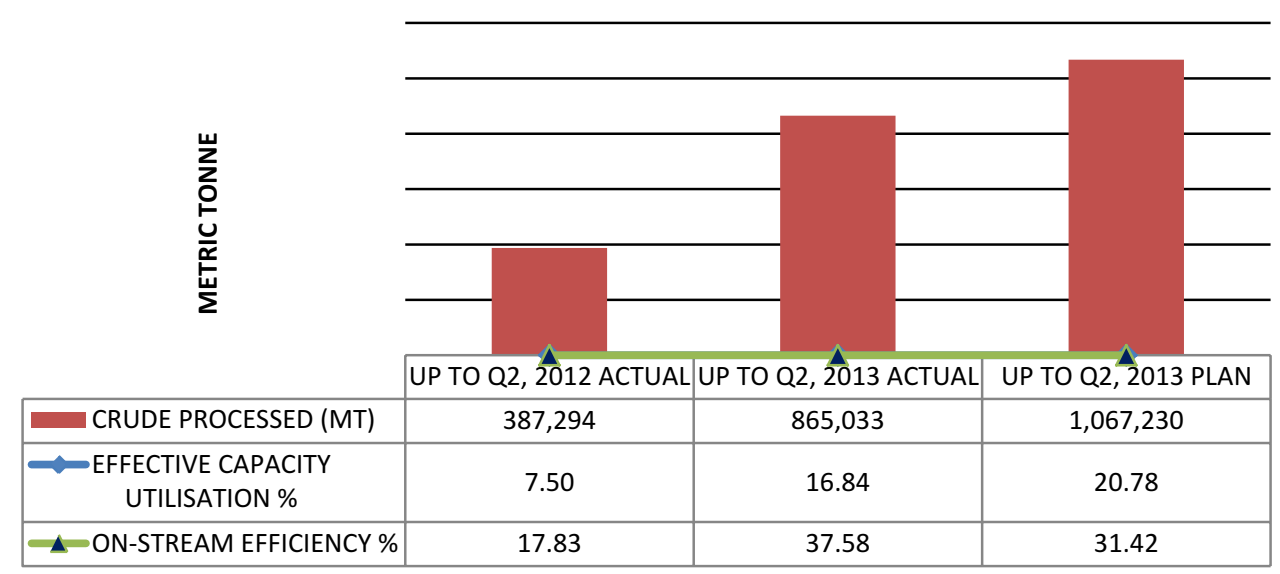

having timely TAM to enable it perform at about $90 \%$ capacity utilization consistently. Non-performance of TAM has resulted in average capacity utilization declining to $20-25 \%$ (see Table 3 and Fig. 3). A more serious consequence is that the country is forced to resort to importation of petroleum products, and massive waste of scarce foreign exchange.

Figure 2 presents the level of production which would have been achieved if the refineries were operating 
efficiently at $90 \%$ capacity. Due to non-performance of TAM, and epileptic supply of crude oil feedstock, actual capacity utilization was much lower. See Table 3 and Fig. 3.

\section{Impact of lack of TAM/rehab on the performance of the refinery}

Machines and other service facilities are subject to deterioration due to their use and exposure to process \& environmental conditions. This deterioration requires to be duly taken care of by various maintenance interventions, techniques and at certain pre-determined intervals so that the required use of facilities can be continued and service life extended until the point where maintenance costs become prohibitive and replacement action becomes inevitable. Our own car periodic service maintenance is an example.

The American Petroleum Institute (API) defines Turnaround as a periodic shutdown (total or partial) of a refinery process unit or plant to perform maintenance, overhaul and repair operations and to inspect, test and replace process materials and equipment.

Turnarounds are critical for the health of a refinery and are the single most costly part of a plant or process plants maintenance budget.

\section{The problem of pipeline vandalization}

The maps that follow indicate the location of the refineries in Nigeria, and the network of pipelines constructed by NNPC for supply of crude oil to the refineries and for evacuation of products (Figs. 4, 5).

As is evident from the two maps above, the refineries were designed to receive crude oil feedstock by pipeline. In like fashion, they were designed to have products evacuated mainly also by pipeline. Lifting of products from depots immediately contiguous to the refineries was intended mainly to supply the towns and cities nearby. The network of pipelines for evacuation of products is shown in Fig. 6.

Vandalization of crude and product pipelines commenced in the late 1990s. Some scholarly works have sought to elucidate the reasons for this development. Two major reasons have been attributed:

- The agitation for resource control and the attendant rise of militancy in the Niger Delta region.

- Outright theft of crude oil and petroleum products.

It could be argued that both are linked. Several publications have given comprehensive treatment of these matters. In summary, the Niger Delta area of Nigeria where oil is principally produced has been a hotbed of agitation for resource control. This has arisen from the perceived injustice felt by the people on the assertion that the region has not significantly benefited from the oil wealth, while it has borne the brunt of resultant environmental degradation and pollution. That is not the subject of this research note.
Fig. 4 Locations of refineries and petrochemical plants

\section{AGING INFRASTRUCTURE}

\section{EXISTING REFINING ASSETS}

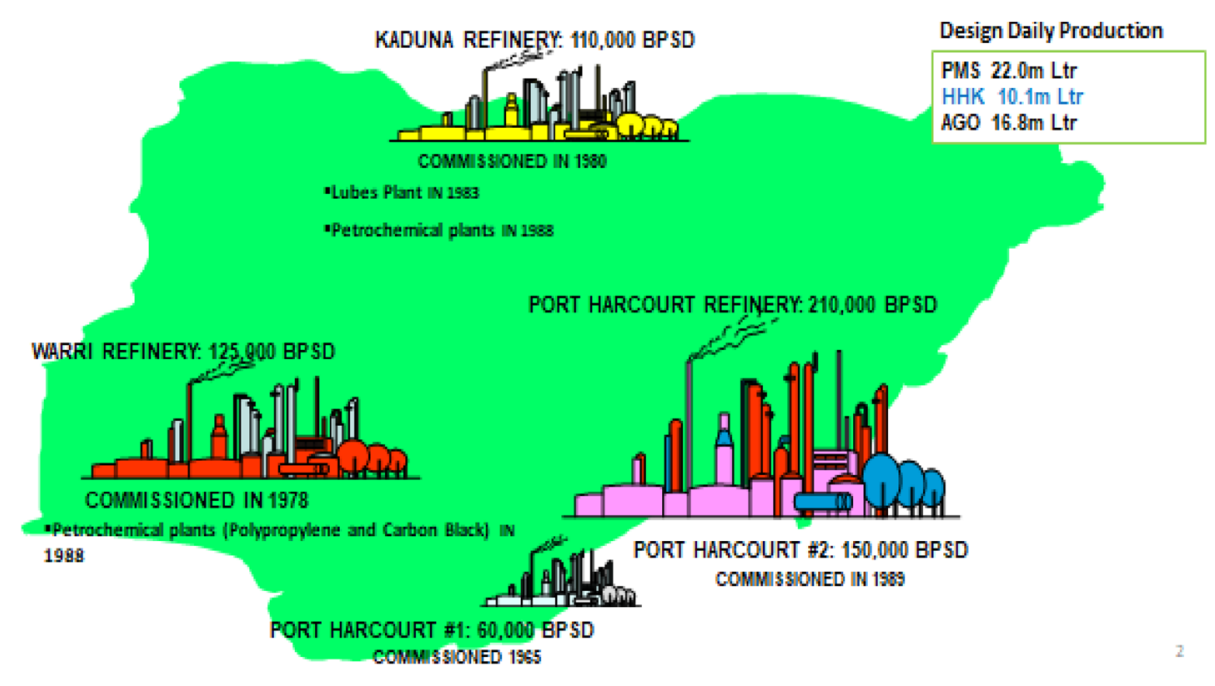




\section{Downstream Infrastructure including Pipelines}

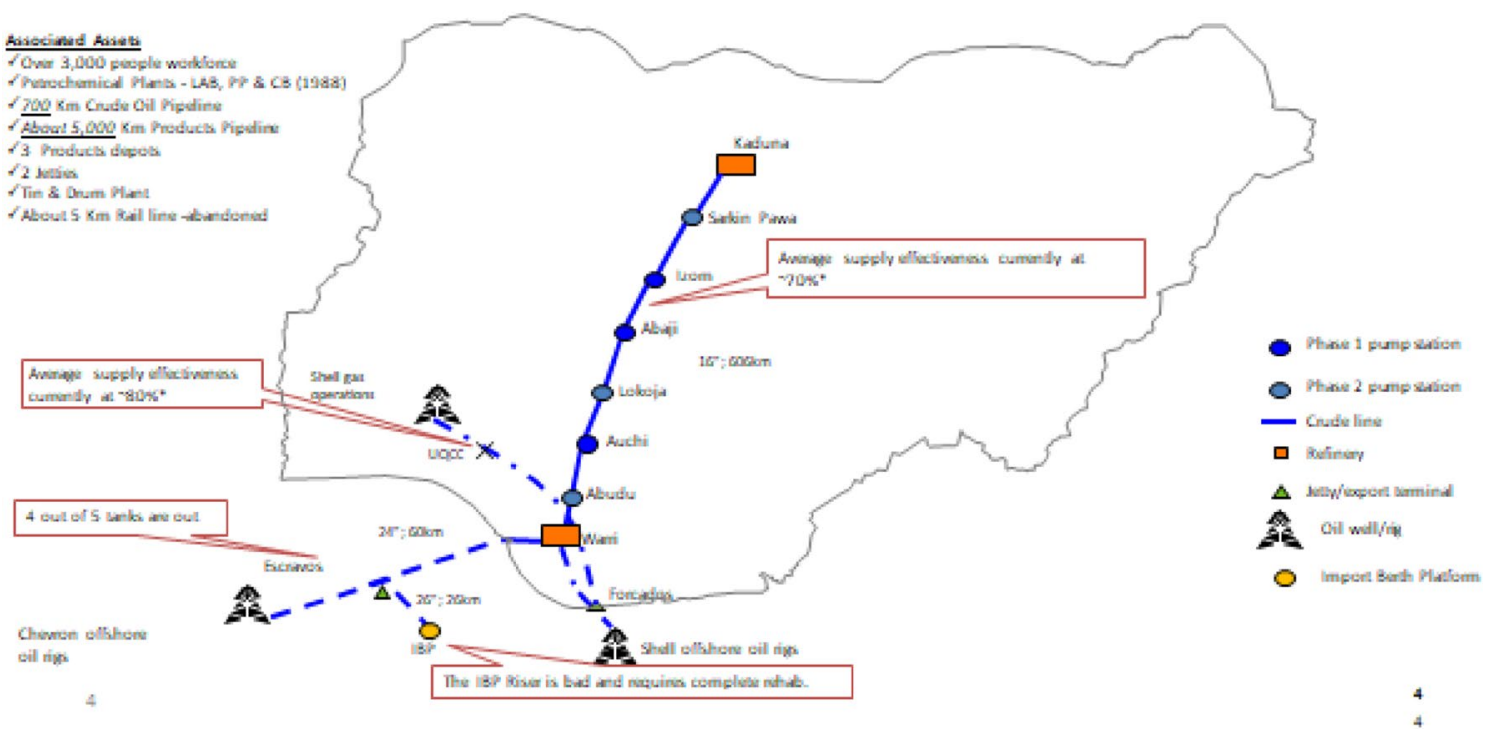

Fig. 5 Crude oil supply pipelines

Fig. 6 Product distribution network

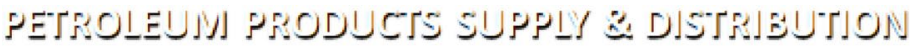 \\ NETYYORS}

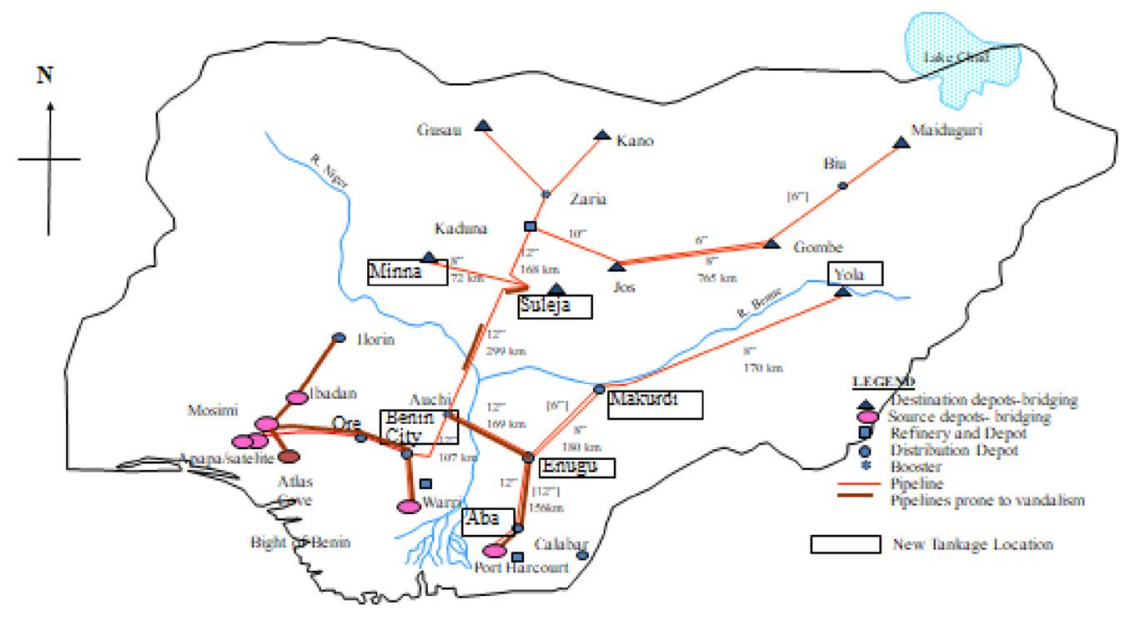

Reference should be made to published works among which are "Oil Wars in the Niger Delta' by Tekena Tamuno [10], and "Legal Issues in the Niger Delta Resource Dilemma" by Akpezi [2]. Suffice it to say that the attacks on the pipelines made it difficult to consistently supply crude oil to the refineries. The poor state of maintenance of the refineries worsened the situation.

An extract from the PHRC Annual report for 2013 highlights the negative impact of pipeline vandalization on crude delivery to the refinery: Please refer to Table 3 hereunder.
An average of $23.46 \%$ and $37.58 \%$ capacity utilization and on-stream efficiency were attained, respectively, as at end of June 2013 for NPHR. Performance of the plant was impeded mainly by inadequate supply of bonny light crude oil.

In Q2 2012, the average capacity utilization and onstream efficiency of New Port Harcourt Refinery (NPHR) were $3.92 \%$ and $6.12 \%$, respectively. This low performance was largely due to low feedstock within the quarter under review. This improved to $12.48 \%$ and $20.43 \%$, respectively, in Q2 2013 when crude oil supply improved slightly. 
The average capacity utilization and on-stream efficiency of FCCU within the period under review were $12.84 \%$ and $16.73 \%$. This low performance was as a result of insufficient feedstock from the upstream vacuum distillation unit, which itself was starved by poor supply to the Crude Unit. Table 3 and Fig. 3 confirm this impact.

Thus, the problem of pipeline vandalization warrants special treatment. The security and safety of the pipeline infrastructure are imperative for the viability of the Downstream Oil and Gas sector.

The frequency of insertions of valves, outright stealing of crude and refined products, bombing of the pipeline by aggrieved and criminal elements have contributed significantly to worsening the on-stream time efficiency of the refineries. These activities have resulted in huge losses to the country as well as degraded the Crude Oil supply and product facilities. Other associated problems include pollution of the environment, fire outbreak, loss of insurance for downstream assets, and shut down of Refineries due to supply chain-related issues.

Evolving a sustainable strategy and approach which includes incorporating additional safety and security features for the pipelines shall minimize and deter this nefarious activity which has significant negative consequences on revenues of the companies and the country at large.

This subject shall be treated under the following five headings:

- State of the Crude and Product Pipeline Infrastructure.

- Pipeline Integrity and Financial Implication.

- Application of Technology to enhance Pipeline safety and security.

- Regulatory framework and Law enforcement.

\section{Present state of the crude and product pipeline infrastructure}

NNPC through its Pipelines and Products Marketing Company (PPMC) manages the facilities and infrastructure for the supply and distribution of crude oil and refined petroleum products (PMS/DPK/AGO). These consist of:

- 5 Terminals.

- 21 Petroleum Depots.

- $750 \mathrm{~km}$ of Crude Oil Pipelines.

- $4400 \mathrm{~km}$ of Products Pipeline Networks.

The crude lines are linked to the export terminals of the major Oil Producing Companies such as Shell Petroleum Development Company (SPDC) and Chevron Nigeria Limited (CNL) which provide the main feedstock for the Refineries totaling 445,000 bpsd capacity.
SPDC is estimated to have over $6000 \mathrm{~km}$ of pipelines and flow lines, 87 flow stations, eight gas plants, two export terminals and more than 1000 producing wells. Chevron on the other hand manages nine Oil mining Leases (OMLs) and one export terminal. The two operating companies provide a large percentage of the crude oil requirement for the Refineries.

Unplanned shut down of any of the crude oil pipelines to these terminals has an immediate impact on the refineries overall performance for that period. A McKinsey report in 2009 provided a correlation between the impact of lack of feedstock and the poor state of reliable operation of the refineries. Supply Chain Issues accounted for $53 \%$ of the unplanned shut downs while equipment failure made up $47 \%$. Matters have been worsened by sabotage of the crude oil pipelines which feed the refineries, and the product evacuation pipelines.

In December 2009, the then Group Managing Director of NNPC, in a two-day series of presentations made separately to the Inspector General of Police, and the Chief of Defence Staff in Abuja elucidated that the advent of illegal bunkering, pipeline vandalism and product theft has massively impacted on the capacity of Nigeria's oil and gas assets to function optimally. He stated that a total of 16,083 pipeline breaks were recorded within the previous 10 years. While 398 pipeline breaks representing $2.4 \%$ were due to ruptures, the remaining 15,685 breaks which translate to about $97.5 \%$ of the total number of cases resulted from the activities of vandals.

Within the same period of 2009,8105 breaks were recorded along the system $2 \mathrm{E}$ representing about $50.3 \%$ of the total number of petroleum products pipeline breaks in the country. The attacks left the NNPC with a cost of N78.15 billion in product loses and pipeline repairs. (The Port Harcourt to Aba segment only came back in service in 2012 after being out for 7 years due to vandalism).

The System 2A product pipeline which conveys products from Warri-Benin-Suleja/Ore depots ranked second on the scale of pipeline break points with 3259 cases representing about $20.2 \%$ of the total. Here again NNPC lost over N20.39 billion in products and pipeline repairs. (The line also was brought back into service in 2012).

System 2B which carries products from the Atlas Cove facility to Mosimi-Satelite-Ibadan-Ilorin depots recorded 2440 breaks leading to a loss of over N73.6 billion in products and pipeline repairs. This zone was the most notorious. In the year 2012 alone, the activities of criminal syndicates caused massive fuel shortages within this axis by shutting off 11 million litres per day of PMS due to the fire outbreak at the Arepo vandalized point. Three NNPC pipeline maintenance staff were murdered while trying to plug the vandalized point. Over 774 line break points were identified and repaired before re-streaming of the line in December 01, 
2012. Miscreants again repeatedly damaged the pipeline in January 2013 resulting in two (2) separate fire outbreaks.

On gas, the incessant attacks on the Trans-Forcados Pipeline rendered it out of service in May 2009, thus making it impossible to evacuate crude oil/condensate from some Shell operated facilities in 2010 with over $300,000 \mathrm{bpd}$ and $140 \mathrm{mscfd}$ production shut-in. About 55 vandalized points were repaired at a cost of N11 billion. In the year 2011 alone, a total of N105 billion was lost due to crude and product theft from pipelines associated with the refineries, from PPMC records.

Due to repeated vandalism of the Escravos-Warri line, NNPC has had to resort to the alternative means of transporting crude oil to WRPC by vessel at an additional cost of \$4.2 per barrel. Over each month, the cost of transporting the contract quantity of crude oil in this manner amounts to $\$ 7$ million; an added burden to the operating costs of the refinery.

While stealing products from pipelines at the Port Harcourt Refinery Jetty, a fire resulted and completely destroyed Jetty B. Jetty A was partially affected. Cost to NNPC for the reconstruction of the Jetty at Okrika is over \$66 million.

The combined impact of these avoidable costs is that the economics of downstream operations is becoming increasingly unattractive and investors are being affected.

\section{Pipeline integrity and financial implication of vandalization}

The incessant attacks have greatly compromised the integrity of the crude and product pipelines because of the constant replacement and repair of the segment.

This development is responsible for the non-attainment of the effective pumping rate of liquids in order to prevent pipeline rupture and consequent environment pollution.

The Energy Information Administration (EIA) Report on Nigeria updated on October 16, 2012, attributes oil theft, commonly referred to as "bunkering", as being responsible for pipeline damage that is often severe, causing loss of production, pollution, and forcing companies to shut in production. Protests from local groups over environmental damages from oil spills and flaring undermined relations between local communities and international oil companies (IOCs). The industry has been unfairly blamed for pollution that has damaged air, soil, and water, leading to losses in arable land and decreasing fish stocks, whereas a significant percentage of the damage is due to activity of vandals.

The report estimates that the theft and trade in stolen oil has recently surged according to NNPC data, by $224 \%$ in 2011 over the previous year. The EIA report quotes Nigeria's Ministry of Finance that about 400,000 bbl/day of oil was stolen in April 2012, which led to a fall of about 17\% in official oil sales. The EIA reports quotes Royal Dutch
Shell, Nigeria's largest producer, recently estimated that $150,000-180,000 \mathrm{bbl} / \mathrm{day}$, or $6 \%$ of the country's total production, on average is lost to oil bunkering and spills.

Using Shell's figure of approximately $(150,000 \mathrm{bbl}$ per day) translates to an average loss in the upstream of $\$ 5.475$ billion per annum. Additionally, Nigeria also lost over N105 billion as theft in the downstream according to PPMC in year 2011 exclusive of pipeline repair cost.

It is, therefore, imperative, given the quantum of financial losses, loss of lives, destruction of property, and environmental degradation that the Country must evolve a strategy to commit about $25 \%$ of the $\$ 5.475$ billion annually over a 10 -year period as pipeline replacement, upgrade, and relocation from ROW, and installation of security surveillance in order to arrest this ugly trend. This should be funded via appropriation by the JVs, PSCs and NNPC under a National Energy Critical Infrastructure Protection and Restoration fund.

\section{Application of technology to enhance pipeline safety and security}

NNPC in collaboration with relevant stakeholders organized a security workshop in October 2012 to discuss and proffer strategies for improving the security of crude supply and evacuation of refined products to and from the Refineries.

The workshop aimed at complementing ongoing Joint Oil and Gas pipeline security committee efforts inaugurated by the Honorable Minister of Petroleum Resources (HMPR) and the Chief of Defense staff to minimize and eradicate crude theft in the oil pipeline. Various interventions, such as engaging communities, Police and Armed Forces for pipeline surveillance, had not stemmed the tide of vandalism. This made it necessary to consider other options, including use of technology to minimize and combat this menace.

The objectives of the workshop among others were to:

- Facilitate the creation of the required synergy among different stakeholders in implementing the new business objective of profitability.

- Explore options available for addressing the problems created through pipelines vandalism;

- Evaluate various technologies that may be applicable in the deployment of the solutions;

- Evaluate the impact of collateral damage to the environment from deploying some of the technologies.

Far reaching solutions and combination of strategies were adopted and recommended to the Federal Government.

Unfortunately, there is evidence that several international syndicates are involved in this nefarious activity. Foreign flagged vessels have been arrested in the Nigerian coastal waters engaged in buying stolen crude oil and products. To 
do nothing means to mortgage the future of Nigeria to continued importation of petroleum products at huge cost and drain of scarce foreign exchange.

\section{Regulatory framework and law enforcement}

A careful review of the Oil Pipelines Act, Cap 338 of 1990 [11] (and the Oil Pipelines Regulations which are made pursuant to the Act) does not establish sanctions for the violation of Pipelines or disruption of the distribution of crude oil or refined petroleum products.

However, the Miscellaneous Offences Act [12] Sect. 1(7) provides that any person who willfully or maliciously breaks, damages, disconnects, tampers with, obstructs, destroys pipelines or interferes with the free flow of crude oil or refined product through pipelines shall be guilty of an offence and liable upon conviction to imprisonment for life. However, the offences under this Act can only be prosecuted at the Federal High Court.

On the other hand, Petroleum Production \& Distribution (Anti-Sabotage Act) [13] Sect. 1 provides that any person who willfully does anything with intent to obstruct or prevent the procurement of petroleum products in any part of Nigeria shall be guilty of an offence of sabotage.

Section 2 states that the persons shall be liable upon conviction to a maximum of 21 years of imprisonment or a Death sentence.

Section 3, however, vests exclusive jurisdiction in the Federal High Court.

The sanctions provided in the relevant laws are severe but the lack of diligent prosecution of offences has rendered the letters of the law ineffective and fueled the impunity with which vandals still operate.

There is a need for Government to enforce the existing sanctions to breeches in illegal act on Pipeline Vandalism and Economic Sabotage and for the National Assembly to harmonize the Oil Pipeline Act to conform to Miscellaneous Act as well as Petroleum Distribution act in order to engender growth in the downstream sector. Furthermore, the Federal Ministry of Justice must as a matter of urgency cooperate on the granting of Fiat to enable private prosecution of offenders.

\section{Case study: USA approach to pipeline safety and security}

In the United States of America, The federal pipeline safety program is authorized under the Pipeline Safety, Regulatory Certainty, and Job Creation Act of 2011 [14] (PL 11290), which was signed by President Obama on January 3, 2012. The act contains a broad range of provisions addressing pipeline safety and security. The federal pipeline security program began with the Department of Transportation
(DOT) as well, immediately after the terror attacks of September 11,2001, but pipeline security authority was subsequently transferred to the Department of Homeland Security (DHS) when the latter department was created. The DOT and DHS have distinct missions, but they cooperate to protect the nation's pipelines.

In addition to their vulnerability to accidents, pipelines may also be intentionally damaged by vandals and terrorists. Pipelines may also be vulnerable to "cyber-attacks" on supervisory control and data acquisition (SCADA) systems or attacks on electricity grids and communications networks. Oil and gas pipelines, globally, have been a favored target of terrorists, militant groups, and organized crime.

On December 17, 2003 [15], President Bush issued Homeland Security Presidential Directive 7 (HSPD-7), clarifying executive agency responsibilities for identifying prioritizing, and protecting critical infrastructure. 53 HSPD-7 maintains DHS as the lead agency for pipeline security (par. 15 ) and instructs the DOT to "collaborate in regulating the transportation of hazardous materials by all modes (including pipelines)" (par. $22 \mathrm{~h}$ ).

The order requires that DHS and other federal agencies collaborate with "appropriate private sector entities" in sharing information and protecting critical infrastructure (par. 25). TSA joined both the Energy Government Coordinating Council and the Transportation Government Coordinating Council under provisions in HSPD-7. The missions of the councils are to work with their industry counterparts to coordinate critical infrastructure protection programs in the energy and transportation sectors, respectively, and to facilitate the sharing of security information.

HSPD-7 also required DHS to develop a national plan for critical infrastructure and key resources protection (par. 27), which the agency issued in 2006 as the National Infrastructure Protection Plan (NIPP). The NIPP, in turn, required each critical infrastructure sector to develop a Sector Specific Plan (SSP) that describes strategies to protect its critical infrastructure, outlines a coordinated approach to strengthen its security efforts, and determines appropriate funding for these activities.

\section{Recommendations to address pipeline vandalization}

- The respective operators should embark on a deliberate program to replace aged or compromised pipelines,

- It is important that Nigeria elevates the issue of pipeline vandalism to the same level as terrorism in order to adequately situate the focus on pipeline safety and security. The pipelines should be declared National Assets and treated as such.

- Funds should be appropriated and deployed for securing the assets under a Federal Government cum Industry 
joint initiative applying appropriate technology and a rapid deployment task force.

\section{The challenge of price control}

The major challenge is the continued regulation of the downstream sector by Government through price control of PMS which accounts for more than $70 \%$ of fuel consumption in Nigeria.

- It makes the economics of refining unprofitable.

- It scares investors.

- It creates an inefficient marketplace.

- It creates an incentive for rent seeking.

- It creates an incentive for smuggling.

- It is an unnecessary drain on national resources through subsidies.

- It does not actually benefit the common man contrary to propaganda.

\section{Opportunities}

In spite of the above, opportunities exist for interested investors to go into refining of petroleum products in Nigeria. Even if all the existing refineries were operating at maximum capacity, there still exists a robust demand for petroleum products in Nigeria. Current aggregate product demand is put at equivalent refining capacity of $800,000 \mathrm{bpsd}$. Hence at least additional 300,000 bpsd capacity is required as at 2018. By 2028, the shortfall in refinery capacity would rise to about 550,000 bpsd assuming a growth rate of $3 \%$ per annum. Furthermore, Nigeria actually supplies petroleum products to neighboring African countries through informal channels. An investor could target to formalize this.

This has informed the decision by the Dangote Group to invest in the construction of a 650,000 bpsd refinery which is expected to come into operation by 2020 or soon after. The actual conventional refinery capacity is 450,000 bpsd, with the other 200,000 bpsd being reserved for petrochemicals feedstock. Thus, there would still be scope for another Greenfield plant of at least 250,000 bpsd capacity, simply to meet Nigeria's needs. A higher capacity would be justified if the intention is to supply the West and Central African regions.

\section{Recommendations}

1. The existing refineries should be rehabilitated and brought back into operation to least at $80-90 \%$ capacity utilization. This is actually a least cost option compared with building Greenfield refineries of equivalent capacities. This can be achieved either through a private sector led financing and rehabilitation initiative as is currently being pursued by NNPC, or through outright divestment of majority equity shareholding to the private sector from the current $100 \%$ ownership by Govt.

2. The refineries should be managed on a fully commercial governance structure in which decision making should rest with the Board of Governors of the Plants, with full control of their funds.

3. The refineries should market their products directly to off-takers, so as to recover maximum value.

4. For the above to succeed, the downstream sector should be freed from government control. Full deregulation will make it attractive for private investors to build refineries to target meeting Nigeria's needs and also that of West and Central Africa. This will also create jobs and grow GDP.

5. Government should create an enabling environment with fiscal incentives to attract investments into refining in Nigeria and make this happen.

6. Those interested in going into modular refining should carry out feasibility studies. The Department of Petroleum Resources should issue licenses and facilitating discussions for access to crude oil feedstock from upstream companies. Modular refineries should be treated as business ventures, not social services.

Open Access This article is distributed under the terms of the Creative Commons Attribution 4.0 International License (http://creativeco mmons.org/licenses/by/4.0/), which permits unrestricted use, distribution, and reproduction in any medium, provided you give appropriate credit to the original author(s) and the source, provide a link to the Creative Commons license, and indicate if changes were made.

\section{References}

1. NNPC archives (2018)

2. Ogbuigwe Akpezi (2018) Legal issues in the Niger Delta resource dilemma. 2nd edn. Anpez Centre for Environment and Development Publications, Port Harcourt, p 11

3. Tamuno S, Felix JM (2006) Crude oil resource: a blessing or a curse to Nigeria-the case of the Niger Delta. J Res Natl Dev 4(2):53

4. Yergin D (1991) The prize. Free Press, New York, p 527

5. Oloruntegbe KO, Akinsete MA, Odutuyi MO (2009) Fifty Years of Oil Exploration in Nigeria: Physicochemical Impacts and Implications for Environmental Accounting and Development. J Appl Sci Res 5(12):2131-2137

6. Ugwukah AC, Ohaja OJ (2016) A historigraphic assessment of the petroleum industry and its impact on the Nigerian economy. Hist Res Lett 36

7. Onojake MC, Osuji LC, Oforka NC (2012) Prelimnary hydrocarbon analysis of crude oils from Umutu/Bomu fields. Egypt J Pet 22(2):217-224 
8. Nigerian National Oil Corporation (NNOC) (2004) now the NNPC act Cap N123, Vol 12 LFN. Laws of the Federal Republic of Nigeria

9. Petroleum Products Pricing and Regulatory Agency (PPPRA) (2012) Refineries data analysis. Laws of the Federal Republic of Nigeria

10. Tamuno TN (2011) Oil wars in the Niger Delta. Laws of the Federal Republic of Nigeria. Stirling-Holden, Ibadan

11. Oil pipelines act, Cap 338 of 1990. Laws of the Federal Republic of Nigeria

12. Miscellaneous offences Act No 18 of 1971, 1984, Section (7). Act of the Congress of the United States of America
13. Petroleum Production and Distributrion (Anti-sabotage act) (1975) Section 1,2,3. Presidential Executive Order

14. USA pipeline security, regulatory certainty and job creation act of 2011 (PL 112-90). A treatise on Resource Control

15. USA homeland security presidential directive 7 (HSPD-7) Dec 17,2003

Publisher's note Springer Nature remains neutral with regard to jurisdictional claims in published maps and institutional affiliations. 